\title{
EFFECT OF COMPOST AND SOME NATURAL STIMULANT TREATMENTS ON: II. CORMS PRODUCTION AND CHEMICAL CONSTITUENTS OF (GLADIOLUS GRANDIFLORUS CV. PETER PEARS) PLANTS
}

\author{
M.A.H. Abdou ${ }^{*}$, F.S. Badran ${ }^{*}$, E.T. Ahmed ${ }^{*}$, R.A. Taha ${ }^{*}$ and M.A.M. Abdel-Mola ${ }^{* *}$ \\ * Hort. Dept., Fac. Agric., Minia Univ., Egypt. \\ ** Hort. Dept., Fac. Agric., Beni-Seuf Univ., Egypt.
}

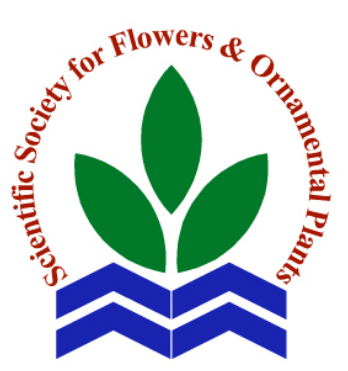

Scientific J. Flowers \& Ornamental Plants, 5(2):115-126 (2018).

Received:

$17 / 2 / 2018$

Accepted:

26/2/2018

ABSTRACT: Two field experiments were conducted to investigate the effect of plant compost (0, 2.5, 5.0 and 7.5 ton/fed) and six natural stimulants (green tea extract at $5 \mathrm{~g} / \mathrm{l}$, moringa leaves extract at 300 $\mathrm{mg} / \mathrm{l}$, garlic extract at $300 \mathrm{mg} / \mathrm{l}$, licorice roots extract at $5 \mathrm{~g} / \mathrm{l}$, active dry yeast at $5 \mathrm{~g} / \mathrm{l}$ and seaweeds extract at $3 \mathrm{~cm}^{3} / \mathrm{l}$ ) on corms production and chemical constituents of Gladiolus grandiflorus cv. Peter Pears.

The obtained results indicated that corm diameter, number of cormels/plant, dry weight of cormels, as well as, chemical constituents including chlorophyll a, b, carotenoids and percentages of $\mathrm{N}, \mathrm{P}$ and $\mathrm{K}$ in the corms were gradually increased by increasing the level of compost. Significant differences were detected among the four used treatments. So, the high level of compost resulted the highest values.

All six treatments of natural stimulants significantly increased corm and cormels production and their content of chemical constituents in comparison of the control plants. The highest values were obtained due to the treatments of seaweeds extract at $3 \mathrm{~cm}^{3} /$ l. or active dry yeast at 5 g/l.

The interaction between compost and natural stimulants was significant for all previous characters, except chlorophyll a in the first season.

Key words: Gladiolus grandiflorus, compost, seaweeds extract, active dry yeast, moringa leaves extract, green tea extract, corms production, chemical constituents.

\section{INTRODUCTION}

Gladiolus grandiflorus, L. plant is considered one of the most important flowering bulbs grown in Egypt. It is known as "Queen" of the bulbous flowers. Its flowers are excellent attractive cut flowers as it lasts longer in flower vase and has magnificent inflorescence with variety of colors.

Organic fertilization and natural stimulants are among the important agricultural treatments which have been proved to improve corm production of gladiolus plants.

The effect of organic fertilization on increasing corm diameter, number of cormels and dry weight of cormels, as well as, chemical constituents of gladiolus plant were reported by many investigators, Zaghloul and Atta-Alla (2001), Ahmed (2013), Sönmez et al. (2013), Saeed et al. (2014), Khalil (2015), Sankari et al. (2015), Hassan (2016) and Khanam et al. (2017).

Active dry yeast treatments and seaweeds extract were found to have 
stimulating effect on corm production and chemical constituents of gladiolus such as those raveled by Al-Rashedy (2010), Ahmed (2013); Abdou and Ibrahim (2015), Khattab et al. (2016), Hassan (2016) and Abdel-Mola (2017).

The aim of this work was to study the effect of application compost fertilization and spraying with some natural stimulants on corm and cormels production, as well as, chemical constituents of Gladiolus grandiflorus cv. Peter Pears.

\section{MATERIALS AND METHODS}

The present study was carried out at the Nursery of Ornamental Plants, Faculty of Agriculture, Minia University during two successive seasons of 2014/2015 and 2015/2016 on gladiolus plants.

Gladiolus grandiflorus cv. Peter Pears corms were obtained from Holland by Basiouny nurseries, Cairo, Egypt. Average corm diameter was 2.7-3.0 cm and corm weight was 9.7-10.2 $\mathrm{g}$ for the first and second seasons, respectively. Corms were planted on October $1^{\text {st }}$ for both seasons in 1.5 $\times 2.2 \mathrm{~m}$ plots containing 3 ridges, $50 \mathrm{~cm}$ apart. Corms were planted in hills, $20 \mathrm{~cm}$ apart (10 corms/ridge) on the lower third of one side of each ridge in clay loam soil. The physical and chemical analysis of the used soil is shown in Table (1).

Split plot design with three replicates was used in this experiment. The four levels of compost fertilization treatments $(0.0,2.5$, 5.0 and 7.5 ton/fed) were considered as main plots and the seven natural stimulant treatments (control, green tea extract at $5 \mathrm{~g} / \mathrm{l}$, moringa leaves extract at $300 \mathrm{mg} / \mathrm{l}$, garlic extract at $300 \mathrm{mg} / \mathrm{l}$, licorice roots extract at 5 $\mathrm{g} / \mathrm{l}$, active dry yeast at $5 \mathrm{~g} / \mathrm{l}$ and seaweeds extract at $3 \mathrm{~cm}^{3} / \mathrm{l}$ ) were put in the sub-plots. The compost was added before planting during the soil preparation. Compost analysis is shown in Table (2).

Natural stimulants were applied, by hand sprayer, three times, one month and two months from planting date and after flowers cut for corm and cormels production. The plants were sprayed till run off. All agricultural practices were performed as usual in the region.

\section{Preparation of the natural stimulants: Garlic plant extract:}

One kilogram fresh mature cloves were blended in the presence of distilled water (1 $\mathrm{kg} / \mathrm{l}$ ), then frozen (24 hours) and thawed two times then filtered. The filter extract (100\%) was used for preparation $(300 \mathrm{ml} / \mathrm{l}=30 \%)$ according to El-Desouky et al. (1998).

Some chemical constituents of garlic according cloves to Arid Land Agricultural Research Unit are listed in Table (3).

\section{Moringa leaves extract:}

Aqueous extract of moringa at $(300 \mathrm{ml} / \mathrm{l})$ was prepared by mixing $30 \mathrm{~g}$ of plant leaf material with one liter of distilled water in a household blender for $15 \mathrm{~min}$ at $50{ }^{\circ} \mathrm{C}$. The solution was filtered through filtered paper (Phiri and Mbewe, 2010). Nutrient information and amino acids of moringa leaves were shown in Table (4).

Table 1. Physical and chemical properties of the experimental soil.

\begin{tabular}{|c|c|c|c|c|c|}
\hline \multirow{2}{*}{ Character } & \multicolumn{2}{|c|}{ Value } & \multirow{2}{*}{ Character } & \multicolumn{2}{|c|}{ Value } \\
\hline & $2014 / 2015$ & 2015/2016 & & $2014 / 2015$ & $2015 / 2016$ \\
\hline Sand (\%) & 28.98 & 28.90 & Total N (\%) & 0.08 & 0.06 \\
\hline Silt (\%) & 29.87 & 30.64 & Available P (\%) & 15.67 & 15.58 \\
\hline Clay (\%) & 41.15 & 40.46 & Exch. K ${ }^{+}(\mathrm{mg} / 100 \mathrm{~g})$ & 2.85 & 2.64 \\
\hline Soil type & Clay loam & Clay loam & Exch. $\mathrm{Ca}^{++}(\mathrm{mg} / 100 \mathrm{~g})$ & 31.12 & 31.43 \\
\hline Organic matter (\%) & 1.54 & 1.59 & Exch. $\mathrm{Na}^{+}(\mathrm{mg} / 100 \mathrm{~g})$ & 2.51 & 2.50 \\
\hline CaCO3 (\%) & 2.11 & 2.10 & $\mathbf{F e}$ & 8.23 & 8.11 \\
\hline pH & 7.75 & 7.71 & DPTA & 2.01 & 2.00 \\
\hline \multirow[t]{2}{*}{ E.C. (mmhos /cm) } & 1.08 & 1.06 & Ext. (ppm) Zn & 2.87 & 2.89 \\
\hline & & & Mn & 8.11 & 8.15 \\
\hline
\end{tabular}


Table 2. The chemical analysis of compost.

\begin{tabular}{lclc}
\multicolumn{1}{c}{ Content } & Value & \multicolumn{1}{c}{ Content } & Value \\
Organic carbon (\%) & 25.1 & Total P (\%) & 0.5 \\
Humidity (\%) & 25 & Total K (\%) & 1.0 \\
Organic matter & 44 & Fe (ppm) & 1750 \\
C/N ratio & 16.7 & Zn (ppm) & 60 \\
pH (1:2.5) & 8.0 & Mn (ppm) & 125 \\
E.C. (mmhos/cm) & 5 & Cu (ppm) & 200 \\
Total N (\%) & 2.2 & & \\
\hline
\end{tabular}

Table 3. Some chemical constituents of garlic according cloves to Arid Land Agricultural Research Unit:

\begin{tabular}{lcccccccc}
\hline Components & $\mathbf{G A}_{3}$ & $\mathbf{I A A}$ & $\mathbf{A B A}$ & $\mathbf{C a}^{+2}$ & $\mathbf{M g}^{+2}$ & $\mathbf{S O}_{\mathbf{4}}^{-2}$ & $\mathbf{Z n}^{+2}$ & $\mathbf{M n}^{+2}$ \\
\hline Concentration & $\begin{array}{c}16.33 \\
\text { (mg/100 g } \\
\text { f.w.) }\end{array}$ & Trace & Trace & $\begin{array}{c}1.363 \\
\%\end{array}$ & $\begin{array}{c}1.230 \\
\%\end{array}$ & $\begin{array}{c}0.181 \\
\%\end{array}$ & $\begin{array}{c}66.5 \\
\text { ppm }\end{array}$ & $\begin{array}{c}94.4 \\
\mathrm{ppm}\end{array}$ \\
\hline
\end{tabular}

Table 4. Nutrients information and amino acids of moringa leaves.

\begin{tabular}{lclclc}
\hline Nutrient information & Leaves & Nutrient information & Leaves & Amino acids & Leaves \\
\hline Calories & 92 & Sulfur (mg) & 137 & Arginine & 402 \\
Protein (g) & 6.7 & Selenium (mg) & 0 & Histidine & 141 \\
Fat (g) & 1.7 & Zinc (mg) & 0 & Isoleucine & 422 \\
Carbohydrate (g) & 13.4 & Oxalic Acid (mg) & 101 & Leucine & 623 \\
Fiber (g) & 0.9 & Vitamin A (mg) & 6.8 & Lysine & 288 \\
Calcium (mg) & 440 & Vitamin B (mg) & 423 & Methionine & 134 \\
Copper (mg) & 1.1 & Vitamin B $\mathbf{( m g )}$ & 0.21 & Phenylalanine & 429 \\
Iron (mg) & 7 & Vitamin B $\mathbf{( m g )}$ & 0.05 & Threonine & 328 \\
Potassium (mg) & 259 & Vitamin B $\mathbf{~ ( m g ) ~}$ & 0.8 & Tryptophan & 127 \\
Magnesium (mg) & 24 & Vitamin C (mg) & 220 & & \\
Phosphorus (mg) & 70 & Vitamin E (mg) & 0 & & \\
\hline
\end{tabular}

\section{Green tea extract:}

The aqueous extract is prepared in ratio 1:10 with the consideration of the absorption coefficient of green tea leaves. Technology of preparation $-5 \mathrm{~g}$ of tea leaves of diameter lower than $5 \mathrm{~mm}$ are poured with $60 \mathrm{ml}$ of boiling water. Time is given for the extraction to cool down and the quality of these extracts has been evaluated after 10, 20 and $30 \mathrm{~min}$ according to Armoskaite et al. (2011).

\section{Active dry yeast:}

The dry matter of active dry yeast (Saccharomyces cerevisiae), was $95 \%$ and live cells were $11.6 \times 10^{9} / \mathrm{g}$. The yeast suspension was prepared by dissolving dry yeast and sugar together $(1: 1) \mathrm{w} / \mathrm{w}$ in warm water $\left(38{ }^{\circ} \mathrm{C}\right)$ and let it stand for two hours before spraying to enhance yeast activity (Skoog and Miller, 1957). Chemical analysis of the dry yeast is presented in Table (5).

\section{Licorice roots extract:}

Preparation of licorice extract soaked grinded dry licorice roots (5 g) in distilled water (1 liter) for 24 hours and then filtered using filter paper. The active components in licorice roots extract contains of volatile oils, tannins, carbohydrates, saponins, phenols, glycosides, flavonoids and fixed oils. 
Table 5. Chemical composition of the used active dry yeast.

\begin{tabular}{|c|c|c|c|c|c|}
\hline Component & Value & Component & Value & Component & Value \\
\hline Cu (mg/g) & 8.0 & Fe (mg/g) & 0.02 & Niacin & $300-500 \mathrm{mg} / \mathrm{g}$ \\
\hline Se (mg/g) & 0.1 & Mg (mg/g) & 1.65 & Pyrodoxin & $28.0 \mathrm{mg} / \mathrm{g}$ \\
\hline Mn (mg/g) & 0.02 & K (mg/g) & 21.0 & Pantathenate & $70.0 \mathrm{mg} / \mathrm{g}$ \\
\hline $\mathrm{Cr}(\mathrm{mg} / \mathrm{g})$ & 2.2 & $P$ (mg/g) & 13.50 & Bioton & $1.3 \mathrm{mg} / \mathrm{g}$ \\
\hline $\mathrm{Ni}(\mathrm{mg} / \mathrm{g})$ & 3.0 & $\mathrm{~S}$ (mg/g) & 3.90 & Cholin & $40.0 \mathrm{mg} / \mathrm{g}$ \\
\hline Va (mg/g) & 0.04 & Zn (mg/g) & 0.17 & Folic acid & $5.13 \mathrm{mg} / \mathrm{g}$ \\
\hline Mo (mg/g) & 0.4 & Si (mg/g) & 0.03 & Vit B12 & $0.001 \mathrm{mg} / \mathrm{g}$ \\
\hline Sn (mg/g) & 3.0 & Proteins & $47 \%$ & Thiamine & $60-100 \mathrm{ml} / \mathrm{g}$ \\
\hline Li (mg/g) & 0.17 & Carbohydrates & $33.0 \%$ & Riboflavin & $35-50 \mathrm{ml} / \mathrm{g}$ \\
\hline Na (mg/g) & 0.12 & Minerals & $8.0 \%$ & Lipids & $4.0 \%$ \\
\hline Ca (mg/g) & 0.75 & Nucleic acids & $8.0 \%$ & & \\
\hline
\end{tabular}

The elements analysis in licorice roots extract contains of $\mathrm{K}, \mathrm{Ca}, \mathrm{Fe}, \mathrm{P}, \mathrm{Mg}, \mathrm{SO}_{4}, \mathrm{~N}$, $\mathrm{Na}, \mathrm{Mn}, \mathrm{Zn}$ and Co. Abd El-Azim et al. (2016). The elements of licorice analysis roots extract listed in Table (6).
Seaweeds extract:

Algeser product contains seaweed extract from (Shoura Chemicals Company, Cairo Alex Desert RD., Giza Governorate). The chemical properties of the seaweeds extract shown in Table (7).

Table 6. The elements of licorice analysis roots extract.

\begin{tabular}{cccccccccccc}
\hline Elements & $\mathbf{K}^{+1}$ & $\mathbf{C a}^{+2}$ & $\mathbf{F e}^{+3}$ & $\mathbf{P}^{-3}$ & $\mathbf{M g}^{+2}$ & $\mathbf{S O 4}^{-2}$ & $\mathbf{N}^{-3}$ & $\mathbf{N a}^{+1}$ & $\mathbf{M n}^{+2}$ & $\mathbf{Z n}^{+2}$ & $\mathbf{C o}^{+2}$ \\
\hline $\mathbf{p p m}$ & 1230 & 500 & 1400 & 520 & 5 & 900 & 16500 & 700 & 1700 & 35000 & 0.07 \\
\hline
\end{tabular}

Table 7. The chemical properties of the seaweeds extract.

\begin{tabular}{lclclc}
\hline \multicolumn{1}{c}{ Character } & Values & \multicolumn{1}{c}{ Character } & Values & Character & Values \\
\hline Moisture \% & 6.0 & K \% & $1.0-1.2$ & Cu ppm & $1.0-6.0$ \\
Organic matter \% & $45-60$ & Mg \% & $0.5-0.9$ & Mn ppm & $5-12$ \\
Inorganic matter \% & $45-60$ & $\mathbf{P} \%$ & $0.02-0.09$ & Zn ppm & $10-100$ \\
Protein \% & $6-8$ & S \% & $3-9$ & Cytokinins \% & 0.02 \\
Carbohydrate \% & $35-50$ & Ca \% & $0.2-1.5$ & IAA \% & 0.03 \\
Aliginic acid \% & $10-20$ & B ppm & $20-100$ & ABA \% & 0.01 \\
Mannitol \% & $4-7$ & Mo ppm & $1-5$ & & \\
Total N \% & $1.0-1.5$ & Fe ppm & $50-200$ & & \\
\hline
\end{tabular}

The following data were recorded:

1. Underground parts characters at harvesting after the foliage had dried (the underground parts were lifted 2 months after cut spikes): corm diameter (cm), number of new cormels/plant and dry weights of cormels (g).

2. Determination of chemical constituents: leaf samples were taken after 75 days from planting to determine chlorophyll a, $\mathrm{b}$ and carotenoids as $\mathrm{mg} / \mathrm{g}$ f.w. using the method described by Moran (1982). The percentages of $\mathrm{N}, \mathrm{P}$ and $\mathrm{K}$ in the dry corms (samples were taken after two months from flowering ending) were estimated according to the methods described by Wilde et al. (1985), Chapman and Pratt (1975) and Cottenie et al. (1982), respectively.

All of the obtained data were tabulated and statistically analyzed according to 
MSTAT- C (1986) and the L.S.D. test at $5 \%$ was followed to compare between the means.

\section{RESULTS AND DISCUSSION}

\section{Corms and cormels production:}

Data in Table (8) indicated that corm diameter, number of cormels/plant and dry weight of cormels/plant during both seasons were significantly increased with increasing compost level in comparison with untreated control plants. Among the three compost treatments, the high level treatment (7.5 ton/fed) resulted the highest values for all corm and cormels production over both low and medium compost treatments in the two seasons. Similar results were also revealed on gladiolus plants by Ruppenthal and Castro (2005), Chandar et al. (2012), Pradeep et al. (2014) Sankari et al. (2015), Hassan (2016) and Khanam et al. (2017).

The increase in the corms and cormels production was attributed to the positive effect of organic fertilizers on improving the vegetative growth, as well as, stimulating the photosynthetic pigments (Table, 9) which reflected on increasing the underground parts of gladiolus.

Concerning natural stimulant treatments, the used six treatments significantly increased corm and cormels production. The highest values were obtained due to the treatments of seaweeds extract at $3 \mathrm{~cm}^{3} / 1$. followed by active dry yeast at $5 \mathrm{~g} / \mathrm{l}$. then licorice roots extract at $5 \mathrm{~g} / \mathrm{l}$. in both seasons. Similar observations were pointed out on gladiolus plants such as Al-Rashedy (2010), Ahmed (2013), Abdou and Ibrahim (2015), Khattab et al. (2016) and Hassan (2016).

The stimulatory effect of the treatments of natural stimulants on corms productivity may due to their mode of action, on the soil or plant, plant hormone, enzymes, amino acids, nutrients and vitamins which came from addition of natural stimulants, and gave better growth consequently increased all corm productivity parameters. (Mady, 2009;
Nagodawithana, 1991; Chapman and Chapman, 1980)

The interaction between the main and sub plot treatments was significant, in both seasons, in regard to corm diameter, cormels dry weight and cormels number/plant. The highest values were obtained for all corm productivity parameters when gladiolus plants received compost at 7.5 ton/fed in combination with seaweeds extract $\left(3 \mathrm{~cm}^{3} / \mathrm{l}\right)$ followed by active dry yeast $(5 \mathrm{~g} / \mathrm{l})$ without significant differences between them in some cases.

\section{Chemical constituents:}

\section{Photosynthetic pigments:}

The contents of chlorophyll a, b and carotenoids in the fresh leaves of Gladiolus cv. Peter Pears were significantly promoted due to compost treatments, in the two growing seasons, in comparison with those of untreated plants as shown in Table (9). The high level of compost ( 7.5 ton/fed) gave the highest values for the three photosynthetic pigments in both seasons. This result may be attributed to the increase in nutrient elements and/or positive role of organic compost on the physical and chemical properties of the soil that reflected on the growth and the pigments content. In harmony with these results regarding organic fertilization treatments were those reported by Abdou et al. (2013), Ahmed et al. (2013), Sankari et al. (2015), Khalil (2015) and Hassan (2016) on gladiolus.

Concerning the influence of natural stimulants treatments, each of chl. a, b and carotenoids contents were significant promoted, in the two experimental seasons, in comparison with control. The highest contents of chl. a, b and carotenoids were obtained with plants received seaweeds extract at $3 \mathrm{~cm}^{3} / \mathrm{l}$ followed by active dry yeast at $5 \mathrm{~g} / \mathrm{l}$ without significant difference between such two superior treatments, except chlorophyll a during the first season. The stimulatory effect of natural stimulant treatments on photosynthetic pigments may be attributed those seaweeds act as plant 
Table 8. Effect of compost and natural stimulants, as well as, their combination treatments on corms and cormels production [corm diameter, number of leaves/plant \& cormels dry weight (g)] of Gladiolus grandiflorus cv. Peter Pears plants during 2014/2015 and 2015/2016 seasons.

\begin{tabular}{|c|c|c|c|c|c|c|c|c|c|c|}
\hline \multirow{3}{*}{$\begin{array}{l}\text { Natural stimulants } \\
\text { treatments (B) }\end{array}$} & \multicolumn{10}{|c|}{ Compost levels (ton/fed) (A) } \\
\hline & \multicolumn{5}{|c|}{$1^{\text {st }}$ season $(2014 / 2015)$} & \multicolumn{5}{|c|}{$2^{\text {nd }}$ season $(2015 / 2016)$} \\
\hline & 0.0 & 2.5 & 5.0 & 7.5 & $\begin{array}{c}\text { Mean } \\
\text { (B) }\end{array}$ & 0.0 & 2.5 & 5.0 & 7.5 & $\begin{array}{c}\text { Mean } \\
(B)\end{array}$ \\
\hline \multicolumn{11}{|c|}{ Corm diameter (cm) } \\
\hline Control & 5.33 & 5.62 & 6.28 & 6.64 & 5.97 & 5.44 & 5.82 & 6.47 & 6.85 & 6.15 \\
\hline Green tea extr. 5 g/l & 5.73 & 5.85 & 6.37 & 6.73 & 6.17 & 5.75 & 6.12 & 6.52 & 7.01 & 6.35 \\
\hline Moringa extr. 300 mg/l & 5.64 & 6.00 & 6.36 & 6.70 & 6.18 & 5.84 & 6.14 & 6.57 & 7.11 & 6.42 \\
\hline Garlic extr. 300 mg/l & 5.94 & 5.97 & 6.41 & 6.51 & 6.21 & 6.08 & 6.17 & 6.61 & 7.12 & 6.50 \\
\hline Licorice extr. 5 g/l & 6.31 & 6.45 & 6.56 & 6.84 & 6.54 & 6.37 & 6.57 & 6.72 & 7.40 & 6.77 \\
\hline Active yeast $5 \mathrm{~g} / \mathrm{l}$ & 6.32 & 6.47 & 6.56 & 6.86 & 6.55 & 6.52 & 6.79 & 6.84 & 7.41 & 6.89 \\
\hline Seaweeds extr. $3 \mathrm{~cm}^{3} / \mathbf{l}$ & 6.34 & 6.48 & 6.58 & 7.13 & 6.63 & 6.58 & 6.80 & 6.84 & 7.43 & 6.91 \\
\hline Mean (A) & 5.94 & 6.12 & 6.45 & 6.77 & & 6.08 & 6.34 & 6.65 & 7.19 & \\
\hline L.S.D. at $5 \%$ & \multicolumn{2}{|c|}{ A: 0.17} & B: 0.21 & \multicolumn{2}{|c|}{ AB: 0.42} & \multicolumn{2}{|c|}{ A: 0.23} & B: 0.15 & \multicolumn{2}{|c|}{ AB: 0.30} \\
\hline \multicolumn{11}{|c|}{ Number of cormels/plant } \\
\hline Control & 27.67 & 32.67 & 34.67 & 36.67 & 32.92 & 28.33 & 31.33 & 33.67 & 35.00 & 32.08 \\
\hline Green tea extr. 5 g/l & 29.00 & 33.33 & 36.67 & 37.67 & 34.17 & 30.33 & 33.33 & 35.00 & 37.67 & 34.08 \\
\hline Moringa extr. 300 mg/l & 32.33 & 35.00 & 37.33 & 38.00 & 35.67 & 33.00 & 35.67 & 37.33 & 39.33 & 36.33 \\
\hline Garlic extr. 300 mg/l & 33.00 & 35.67 & 38.33 & 39.00 & 36.50 & 34.67 & 37.33 & 38.67 & 40.67 & 37.84 \\
\hline Licorice extr. 5 g/l & 35.33 & 37.67 & 38.67 & 39.67 & 37.84 & 36.33 & 38.33 & 40.67 & 43.00 & 39.58 \\
\hline Active yeast $5 \mathrm{~g} / \mathrm{l}$ & 36.33 & 38.67 & 40.00 & 41.33 & 39.08 & 36.67 & 40.67 & 42.00 & 43.33 & 40.67 \\
\hline Seaweeds extr. $3 \mathrm{~cm}^{3} / \mathbf{l}$ & 37.33 & 39.00 & 40.00 & 42.00 & 39.58 & 38.00 & 42.00 & 43.00 & 45.00 & 42.00 \\
\hline Mean (A) & 33.00 & 36.00 & 37.95 & 39.19 & & 33.90 & 36.95 & 38.62 & 40.57 & \\
\hline L.S.D. at $5 \%$ & \multicolumn{2}{|c|}{ A: 2.24} & B: 1.22 & \multicolumn{2}{|c|}{ AB: 2.44} & \multicolumn{2}{|c|}{ A: 2.55} & B: 1.94 & \multicolumn{2}{|c|}{ AB: 3.88} \\
\hline \multicolumn{11}{|c|}{ Cormels dry weight (g) } \\
\hline Control & 5.49 & 6.84 & 7.47 & 7.68 & 6.87 & 6.60 & 7.81 & 7.99 & 9.18 & 7.90 \\
\hline Green tea extr. 5 g/l & 6.05 & 7.20 & 7.94 & 8.11 & 7.33 & 7.29 & 7.98 & 8.29 & 10.15 & 8.43 \\
\hline Moringa extr. 300 mg/l & 6.15 & 7.25 & 8.02 & 8.15 & 7.39 & 7.32 & 8.36 & 8.64 & 10.18 & 8.63 \\
\hline Garlic extr. 300 mg/l & 7.91 & 8.00 & 8.14 & 8.32 & 8.09 & 8.57 & 8.61 & 8.71 & 10.55 & 9.11 \\
\hline Licorice extr. 5 g/l & 7.94 & 8.09 & 8.17 & 8.55 & 8.19 & 8.60 & 8.67 & 8.75 & 10.93 & 9.24 \\
\hline Active yeast $5 \mathrm{~g} / \mathrm{l}$ & 8.11 & 8.29 & 8.34 & 8.73 & 8.37 & 8.69 & 8.73 & 8.81 & 11.49 & 9.43 \\
\hline Seaweeds extr. $3 \mathrm{~cm}^{3} / \mathrm{l}$ & 8.22 & 8.34 & 8.77 & 9.65 & 8.75 & 8.73 & 8.87 & 8.96 & 11.82 & 9.60 \\
\hline Mean (A) & 7.12 & 7.72 & 8.12 & 8.46 & & 7.97 & 8.43 & 8.59 & 10.61 & \\
\hline L.S.D. at $5 \%$ & A: 0.5 & & B: 0.42 & $\mathrm{AB}$ & 0.84 & A: 0. & & B: 0.50 & & 1.00 \\
\hline
\end{tabular}


Table 9. Effect of compost and natural stimulants, as well as, their combination treatments on three Photosynthetic pigments (chlorophyll a, b and carotenoids) of Gladiolus grandiflorus cv. Peter Pears plants during 2014/2015 and 2015/2016 seasons.

\begin{tabular}{|c|c|c|c|c|c|c|c|c|c|c|}
\hline \multirow{3}{*}{$\begin{array}{c}\text { Natural stimulants } \\
\text { treatments (B) }\end{array}$} & \multicolumn{10}{|c|}{ Compost levels (ton/fed) (A) } \\
\hline & \multicolumn{5}{|c|}{$1^{\text {st }}$ season $(2014 / 2015)$} & \multicolumn{5}{|c|}{$2^{\text {nd }}$ season $(2015 / 2016)$} \\
\hline & 0.0 & 2.5 & 5.0 & 7.5 & $\begin{array}{c}\text { Mean } \\
\text { (B) }\end{array}$ & 0.0 & 2.5 & 5.0 & 7.5 & $\begin{array}{c}\text { Mean } \\
\text { (B) }\end{array}$ \\
\hline \multicolumn{11}{|c|}{ Chlorophyll a (mg/g f.w.) } \\
\hline Control & 2.432 & 2.483 & 2.534 & 2.605 & 2.514 & 2.491 & 2.541 & 2.586 & 2.641 & 2.565 \\
\hline Green tea extr. 5 g/l & 2.472 & 2.502 & 2.542 & 2.592 & 2.527 & 2.531 & 2.576 & 2.631 & 2.696 & 2.609 \\
\hline Moringa extr. 300 mg/l & 2.493 & 2.534 & 2.574 & 2.625 & 2.557 & 2.550 & 2.595 & 2.650 & 2.715 & 2.628 \\
\hline Garlic extr. 300 mg/l & 2.522 & 2.563 & 2.604 & 2.655 & 2.586 & 2.581 & 2.626 & 2.681 & 2.746 & 2.659 \\
\hline Licorice extr. 5 g/l & 2.548 & 2.569 & 2.630 & 2.681 & 2.607 & 2.606 & 2.646 & 2.691 & 2.752 & 2.674 \\
\hline Active yeast $5 \mathrm{~g} / \mathrm{l}$ & 2.579 & 2.620 & 2.661 & 2.712 & 2.643 & 2.635 & 2.665 & 2.704 & 2.764 & 2.692 \\
\hline Seaweeds extr. $3 \mathrm{~cm}^{3} / \mathbf{l}$ & 2.597 & 2.641 & 2.692 & 2.752 & 2.671 & 2.656 & 2.686 & 2.735 & 2.795 & 2.718 \\
\hline Mean (A) & 2.520 & 2.559 & 2.605 & 2.660 & & 2.579 & 2.619 & 2.668 & 2.730 & \\
\hline L.S.D. at $5 \%$ & \multicolumn{2}{|c|}{ A :0.038 } & : 0.011 & \multicolumn{2}{|c|}{ AB :N.S. } & \multicolumn{2}{|c|}{ A :0.031 } & B :0.041 & \multicolumn{2}{|c|}{ AB :0.082 } \\
\hline \multicolumn{11}{|c|}{ Chlorophyll b (mg/g f.w.) } \\
\hline Control & 0.858 & 0.875 & 0.893 & 0.916 & 0.886 & 0.878 & 0.895 & 0.910 & 0.928 & 0.903 \\
\hline Green tea extr. 5 g/l & 0.882 & 0.892 & 0.905 & 0.922 & 0.900 & 0.893 & 0.906 & 0.925 & 0.946 & 0.918 \\
\hline Moringa extr. 300 mg/l & 0.890 & 0.903 & 0.917 & 0.932 & 0.911 & 0.898 & 0.913 & 0.930 & 0.954 & 0.924 \\
\hline Garlic extr. 300 mg/l & 0.898 & 0.911 & 0.925 & 0.941 & 0.919 & 0.908 & 0.924 & 0.938 & 0.960 & 0.933 \\
\hline Licorice extr. $5 \mathrm{~g} / \mathrm{l}$ & 0.907 & 0.921 & 0.933 & 0.951 & 0.928 & 0.917 & 0.930 & 0.955 & 0.962 & 0.941 \\
\hline Active yeast $5 \mathrm{~g} / \mathrm{l}$ & 0.918 & 0.930 & 0.942 & 0.958 & 0.937 & 0.926 & 0.936 & 0.956 & 0.969 & 0.947 \\
\hline Seaweeds extr. $3 \mathrm{~cm}^{3} / \mathrm{l}$ & 0.925 & 0.937 & 0.953 & 0.972 & 0.947 & 0.933 & 0.943 & 0.960 & 0.978 & 0.954 \\
\hline Mean (A) & 0.897 & 0.910 & 0.924 & 0.942 & & 0.908 & 0.921 & 0.939 & 0.957 & \\
\hline L.S.D. at $5 \%$ & \multicolumn{2}{|c|}{ A :0.012 } & 012 & \multicolumn{2}{|c|}{ AB $: 0.024$} & \multicolumn{2}{|c|}{ A :0.012 } & B :0.013 & \multicolumn{2}{|c|}{$A B: 0.026$} \\
\hline \multicolumn{11}{|c|}{ Carotenoids (mg/g f.w.) } \\
\hline Control & 0.938 & 0.955 & 0.973 & 0.997 & 0.966 & 0.998 & 1.015 & 1.030 & 1.048 & 1.023 \\
\hline Green tea extr. 5 g/l & 0.982 & 0.992 & 1.006 & 1.022 & 1.001 & 1.012 & 1.026 & 1.044 & 1.066 & 1.037 \\
\hline Moringa extr. 300 mg/l & 0.993 & 1.002 & 1.015 & 1.034 & 1.011 & 1.018 & 1.033 & 1.051 & 1.073 & 1.044 \\
\hline Garlic extr. 300 mg/l & 0.999 & 1.013 & 1.026 & 1.045 & 1.021 & 1.029 & 1.045 & 1.063 & 1.082 & 1.055 \\
\hline Licorice extr. 5 g/l & 1.008 & 1.022 & 1.035 & 1.054 & 1.030 & 1.038 & 1.052 & 1.065 & 1.087 & 1.061 \\
\hline Active yeast $5 \mathrm{~g} / \mathrm{l}$ & 1.021 & 1.033 & 1.046 & 1.065 & 1.041 & 1.047 & 1.056 & 1.067 & 1.090 & 1.065 \\
\hline Seaweeds extr. $3 \mathrm{~cm}^{3} / 1$ & 1.026 & 1.043 & 1.056 & 1.077 & 1.051 & 1.054 & 1.064 & 1.080 & 1.100 & 1.075 \\
\hline Mean (A) & 0.995 & 1.009 & 1.022 & 1.042 & & 1.028 & 1.042 & 1.057 & 1.078 & \\
\hline L.S.D. at $5 \%$ & $A: 0.0$ & & :0.032 & $\mathrm{AB}$ & 0.064 & $\mathrm{~A}: 0$. & & B :0.012 & & 0.024 \\
\hline
\end{tabular}


growth regulators stimulants in peolonged chlorophyll production and photosynthesis (Aitken and Senn, 1965). Also, yeast is considered as a natural source of cytokinns that stimulate the synthesis of proteins, nucleic acid and chlorophyll (Fathy and Farid, 1996). Our results are in some direction with Ahmed (2013), Hassan (2016) and Khattab et al. (2016) on gladiolus.

The interaction between main and sub plots $(A \times B)$ was significant for chlorophyll a, b and carotenoids, except, chlorophyll a in the first season. The highest values being obtained due to fertilizing plants with compost at 7.5 ton/fed. and spraying plants with seaweeds extract at $3 \mathrm{~cm}^{3} / 1$.

\section{Corms content of nitrogen, phosphorus and potassium as percentages:}

In both seasons, increasing the level of compost linearly increased the percentages of $\mathrm{N}, \mathrm{P}$ and $\mathrm{K}$ in the corms. In this concern, the treatment with high level of compost (7.5 ton/fed) gave the highest percentages (Table, 10). On the other hand, the lowest values of $\mathrm{N}, \mathrm{P}$ and $\mathrm{K}$ in the corms of gladiolus were recorded by the plants treated without organic fertilization.

The results mentioned above, could be attributed to that application of compost improved soil properties, increase nutrients in area of roots, which increase nutrients uptake which in turn reflects on the corm quality.

These results are in agreement with those obtained by Zaghloul and Atta-Alla (2001), Sönmez et al. (2013), Saeed et al. (2014) and Hassan (2016) on gladiolus.

In regard with natural stimulant treatments, significant differences were obtained due to the used of any one, in comparison with control treatment. Most effective treatment among these six treatments, for the three nutrients percentage was treatment of seaweeds extract followed by dry yeast without significant differences between them in the two growing seasons.
Seaweeds liquid contained macronutrients, trace elements, organic substances like amino acids and plant growth regulators such as auxins, cytokinins and gibberellins, as well as, vitamins and fatty acids (Chapman and Chapman 1980). Also, yeast can play a very significant role in making available nutrient elements for plant (Khalil and Ismael, 2010). These positive effects of the used treatments led to promoted nutrient uptake and finally reflexes on the corms percentages of $\mathrm{N}, \mathrm{P}$ and $\mathrm{K}$.

Hassan (2016) and Abdel-Mola (2017) on gladiolus found that seaweeds extract treatment increased NPK \% in corms. Moreover, Ahmed (2013) and Abdel-Mola (2017) concluded that active dry yeast treatment increased $\mathrm{N}, \mathrm{P}$ and $\mathrm{K} \%$ in corms of gladiolus.

Effect of the interaction treatments was significant, in both seasons, for NPK \% in corms. The highest values for $\mathrm{N}, \mathrm{P}$ and $\mathrm{K} \%$ in corms were obtained due to fertilizing plants with high level of compost (7.5 ton/fed.) plus treating plants with seaweeds extract $\left(3 \mathrm{~cm}^{3} / \mathrm{l}\right)$ followed by active dry yeast (5 g/l) without significant differences between them except in $\mathrm{K} \%$ in the two growing seasons.

\section{REFERENCES}

Abd El-Azim, W.M.; Badawy, M.Y.M. and Khater, R.M.R. (2016). Effect of Mycorrhiza and phosphate dissolving bacteria and licorice extract on growth and oil productivity of Foeniculum vulgare, mill. Plant under Baluza in North Sinai conditions. Middle East J. of Applied Sciences, 6(4):990-1002.

Abdel-Mola, M.A.M. (2017). Response of Gladiolus grandiflorus Plants to Compost Fertilization and Some Natural Stimulants. Ph.D. Thesis, Fac. Agric., Minia University.

Abdou, M.A.H.; Aly, M.K. and Ahmed, A.S.A. (2013). Effect of compost, biofertilization and some vitamins addition on Gladiolus grandiflorus J. 
Table 10. Effect of compost and natural stimulants, as well as, their combination treatments on NPK percentages in dry corms of Gladiolus grandiflorus cv. Peter Pears plants during 2014/2015 and 2015/2016 seasons.

\begin{tabular}{|c|c|c|c|c|c|c|c|c|c|c|}
\hline \multirow{3}{*}{$\begin{array}{l}\text { Natural stimulants } \\
\text { treatments (B) }\end{array}$} & \multicolumn{10}{|c|}{ Compost levels (ton/fed) (A) } \\
\hline & \multicolumn{5}{|c|}{$1^{\text {st }} \operatorname{season}(2014 / 2015)$} & \multicolumn{5}{|c|}{$2^{\text {nd }}$ season $(2015 / 2016)$} \\
\hline & 0.0 & 2.5 & 5.0 & 7.5 & $\begin{array}{c}\text { Mean } \\
\text { (B) }\end{array}$ & 0.0 & 2.5 & 5.0 & 7.5 & $\begin{array}{c}\text { Mean } \\
\text { (B) }\end{array}$ \\
\hline \multicolumn{11}{|c|}{$\mathrm{N} \%$ in corms } \\
\hline Control & 0.415 & 0.436 & 0.466 & 0.506 & 0.456 & 0.422 & 0.438 & 0.469 & 0.515 & 0.461 \\
\hline Green tea extr. 5 g/l & 0.474 & 0.515 & 0.546 & 0.585 & 0.530 & 0.487 & 0.518 & 0.550 & 0.596 & 0.538 \\
\hline Moringa extr. 300 mg/l & 0.495 & 0.534 & 0.569 & 0.609 & 0.552 & 0.498 & 0.560 & 0.595 & 0.640 & 0.573 \\
\hline Garlic extr. 300 mg/l & 0.526 & 0.589 & 0.624 & 0.665 & 0.601 & 0.528 & 0.596 & 0.632 & 0.676 & 0.608 \\
\hline Licorice extr. 5 g/l & 0.545 & 0.610 & 0.660 & 0.676 & 0.623 & 0.550 & 0.621 & 0.650 & 0.690 & 0.628 \\
\hline Active yeast $5 \mathrm{~g} / \mathrm{l}$ & 0.574 & 0.651 & 0.673 & 0.720 & 0.655 & 0.587 & 0.658 & 0.680 & 0.718 & 0.661 \\
\hline Seaweeds extr. $3 \mathrm{~cm}^{3} / \mathbf{l}$ & 0.576 & 0.652 & 0.675 & 0.721 & 0.656 & 0.588 & 0.659 & 0.682 & 0.720 & 0.662 \\
\hline Mean (A) & 0.515 & 0.570 & 0.602 & 0.640 & & 0.523 & 0.579 & 0.608 & 0.651 & \\
\hline L.S.D. at $5 \%$ & \multicolumn{2}{|c|}{ A :0.031 } & B :0.072 & \multicolumn{2}{|c|}{$\mathrm{AB}: 0.144$} & \multicolumn{2}{|c|}{ A : 0.025} & B :0.074 & \multicolumn{2}{|c|}{ AB :0.148 } \\
\hline \multicolumn{11}{|c|}{$P \%$ in corms } \\
\hline Control & 0.302 & 0.359 & 0.380 & 0.388 & 0.357 & 0.311 & 0.367 & 0.390 & 0.390 & 0.365 \\
\hline Green tea extr. 5 g/l & 0.328 & 0.378 & 0.393 & 0.408 & 0.377 & 0.334 & 0.385 & 0.402 & 0.417 & 0.385 \\
\hline Moringa extr. 300 mg/l & 0.335 & 0.389 & 0.402 & 0.412 & 0.385 & 0.334 & 0.390 & 0.407 & 0.417 & 0.387 \\
\hline Garlic extr. 300 mg/l & 0.338 & 0.392 & 0.408 & 0.422 & 0.390 & 0.342 & 0.397 & 0.414 & 0.429 & 0.396 \\
\hline Licorice extr. $5 \mathrm{~g} / \mathrm{l}$ & 0.339 & 0.396 & 0.411 & 0.426 & 0.393 & 0.344 & 0.402 & 0.418 & 0.434 & 0.400 \\
\hline Active yeast $5 \mathrm{~g} / \mathrm{l}$ & 0.345 & 0.405 & 0.433 & 0.443 & 0.407 & 0.349 & 0.412 & 0.440 & 0.443 & 0.411 \\
\hline Seaweeds extr. $3 \mathrm{~cm}^{3} / \mathrm{l}$ & 0.345 & 0.405 & 0.433 & 0.444 & 0.407 & 0.350 & 0.410 & 0.440 & 0.444 & 0.411 \\
\hline Mean (A) & 0.333 & 0.389 & 0.409 & 0.420 & & 0.338 & 0.395 & 0.416 & 0.425 & \\
\hline L.S.D. at $5 \%$ & \multicolumn{2}{|c|}{ A :0.010 } & B :0.012 & \multicolumn{2}{|c|}{ AB :0.024 } & \multicolumn{2}{|c|}{ A :0.007 } & B :0.016 & \multicolumn{2}{|c|}{$\mathrm{AB}: 0.032$} \\
\hline \multicolumn{11}{|c|}{$\mathrm{K} \%$ in corms } \\
\hline Control & 1.203 & 1.415 & 1.499 & 1.548 & 1.416 & 1.224 & 1.416 & 1.499 & 1.548 & 1.422 \\
\hline Green tea extr. 5 g/l & 1.235 & 1.448 & 1.529 & 1.579 & 1.448 & 1.250 & 1.453 & 1.529 & 1.583 & 1.454 \\
\hline Moringa extr. 300 mg/l & 1.246 & 1.459 & 1.539 & 1.589 & 1.458 & 1.261 & 1.462 & 1.538 & 1.590 & 1.463 \\
\hline Garlic extr. 300 mg/l & 1.254 & 1.467 & 1.547 & 1.609 & 1.469 & 1.270 & 1.462 & 1.538 & 1.590 & 1.465 \\
\hline Licorice extr. 5 g/l & 1.265 & 1.478 & 1.559 & 1.617 & 1.480 & 1.280 & 1.471 & 1.547 & 1.599 & 1.474 \\
\hline Active yeast $5 \mathrm{~g} / \mathbf{l}$ & 1.274 & 1.496 & 1.570 & 1.626 & 1.492 & 1.291 & 1.487 & 1.562 & 1.616 & 1.489 \\
\hline Seaweeds extr. $3 \mathrm{~cm}^{3} / \mathbf{l}$ & 1.282 & 1.488 & 1.577 & 1.628 & 1.494 & 1.294 & 1.489 & 1.565 & 1.618 & 1.492 \\
\hline Mean (A) & 1.251 & 1.464 & 1.546 & 1.599 & & 1.267 & 1.463 & 1.540 & 1.592 & \\
\hline L.S.D. at $5 \%$ & \multicolumn{2}{|c|}{ A :0.049 } & B :0.029 & \multicolumn{2}{|c|}{ AB :0.058 } & \multicolumn{2}{|c|}{ A $: 0.045$} & B :0.031 & \multicolumn{2}{|c|}{ AB :0.062 } \\
\hline
\end{tabular}


Plant Production, Mansoura Univ., 4(12):1751-1761.

Abdou, M.A.H. and Ibrahim, T.I.E. (2015). Response of Gladiolus cv. Carmen to compost, biofertilization and some vitamin treatments. The $1^{\text {st }}$ Conf. of SSFOP "Future of Ornamental Plants in Egypt", Cairo, Egypt, 22/2/2015, Scientific J. Flowers \& Ornamental Plants.

Ahmed, A.S.A. (2013). Physiological Studies on Gladiolus Plant. M.Sc. Thesis, Fac. Agric. Minia Univ. Egypt., 1-159.

Ahmed, I.; Saquib, R.U.; Qasim, M.; Saleem, M.; Khan, A.S. and Yaseen, M. (2013). Humic acid and cultivar effects on growth, yield, vase life and corm characteristics of gladiolus. Chilean J. of Agri. Res., 73(4):339-344.

Aitken, J. and Senn, T. (1965). Seaweed products as a fertilizer and soil conditioner. Botanica Marina, 8:144.

Al-Rashedy, G.A.H. (2010). Effect of Some Treatments on Growth, Flowering, Corms and Cormels Yield of Two Gladiolus Hortulanus Cultivars. M.Sc. Thesis, Fac. Agric., Univ. of Mosul. Iraq.

Armoskaite, V.; Ramanauskiene, K.; Maruska, A.; Razukas, A.; Dagilyte, A.; Baranauskas, A. and Briedis, V. (2011). The analysis of quality and antioxidant activity of green tea extracts. J. of Medicinal Plants Res., 5(5):811-816.

Chandar, I.; Rawat, I.; Lakhawat, S.S. and Yadav, K.K. (2012). Effect of organic manures and biofertilizers on the yield parameters of Gladiolus cv. White prosperity. Ecol., Environ. and Conservation Paper,18(1):91-94.

Chapman, H.D. and Pratt, P.F. (1975). Methods of Analysis for Soil, Plant and Water Calif. Univ. Division of Agric. Sci., 172-174.

Chapman, V.J. and Chapman, D.J. (1980). Seaweeds and their uses. $3^{\text {rd }}$ edition.
Chapman and Hall, London, New York., pp: 30-42.

Cottenie, A.; Verloo, M.; Velghe, M. and Camerlynck, R. (1982). Chemical Analysis of Plant and Soil. Laboratory of Analytical and Agro Chemistry. State Univ., Ghent, Belgium.

El-Desouky, S.A.; Waneis, A.L.A. and Khedr, Z.M.A. (1998). Utilization of some natural plant extracts (garlic and yeast) as seed-soaked materials to squash (Cucurbita pepo, L.). Effect on growth, sex expression and fruit yield and quality. Ann. Agric., Sci., Moshtohor, 36(2):839854.

Fathy, S.L. and Farid, S. (1996). Effect of some chemical treatments, yeast preparation and royal Jelly on some vegetable crops growing in late summer season to induce their ability towards better thermal tolerance. J. Agric. Sci., Mansoura Univ., 25(4):2215-2249.

Hassan, A.A. (2016). Response of Gladiolus Plant to Some Fertilization and Antioxidant Treatments. Ph.D. Thesis, Fac. Agric., Minia University.

Khalil, A.R.M. (2015). Physiological Studies on Gladiolus Plant. M.Sc. Thesis, Fac. Agric. Minia Univ. Egypt., 1-146.

Khalil, S. E. and Ismael, E. G. (2010). Growth, yield and seed quality of Lupinus termis as affected by different soil moisture levels and different ways of yeast application. Journal of American Science, 6(8):141-153.

Khanam, R.; Kundu, D. and Patra, S. (2017). Integrated nutrient management on growth, quality, and yield and soil fertility of gladiolus in lower Gangetic plain of India. International J. of Current Microbiology and Appl. Sci., 6(4):453459.

Khattab, M.; Raslan, M.; Nabih, A. and Selim, A. (2016). Effect of some fertilizer treatments on the growth of cormels of Gladiolus and corms 
production. Alexandria Science Exchange Journal, 37(4):561-571.

Mady, H.S. (2009). Effect of Certain Medicinal Plant Extracts on Growth, Yield and Metabolism of Some Medicinal and Aromatic Plants. M.Sc. Thesis, Fac. Sci., Al-Azher Univ.

Moran, R. (1982). Formula determination of chlorophylls pigments extracted with $\mathrm{N}$ dimethyl formamide. Plant Physiology, 69:1376-1381.

MSTAT-C (1986). A microcomputer program for the Design Management and Analysis of Agronomic Research Experiments (Version 4.0), Michigan State Univ., U.S.A.

Nagodawithana, W.T. (1991). Yeast Technology. Universal Foods Corporation Milwaukee, Wisconsin Published by Van Nostrand Reinhold, New York, 273 pp.

Phiri, C. and Mbewe, D.N. (2010). Influence of Moringa oliefera, leaf extracts on germination and seedling survival of three common legumes. Int. J. Agric. Biol., 12:315-317.

Pradeep, K.; Manivannan, K. and Kumar, S.R. (2014). Effect of organic nutrients on growth, flowering and yield of Gladiolus grandiflorus, L. The Asian J. of Hort., 9(2):416-420.

Ruppenthal, V. and Castro, A.M.C. (2005). Effect of Urban Waste Compost on nutrition and yield of gladiolus. R. Bras. Ci. Solo., 29:145-150.

Saeed, R.M.; Bazaraa, W.M. and Nabih, A. (2014). Effect of growing media, organic fertilization and biostimulants on the production of Gladiolus (cv. Novalux) corms from cormlets. Scientific J. Flowers \& Ornamental Plants, 1(1):7387.

Sankari, A.; Anand, M. and Arulmozhiyan, R. (2015). Effect of biostimulants on yield and post-harvest quality of Gladiolus cv. White prosperity. The Asian J. of Hort., 10(1):86- 94.

Skoog, F. and Miller, C. (1957). Biological action of growth substances. Cambridge Univ. Press Camb., 1957-2000.

Sönmez, F.; Cig, A.; Gülser, F. and Basdogan, G. (2013). The effects of some organic fertilizers on nutrient contents in hybrid gladiolus. Eurasian J. of Soil Sci., 2:140-144.

Wilde, S.A.; Covey, R.P.; Lyer, J.C. and Voigt, G.K. (1985). Soil and Plant Analysis for Tree Culture. Oxford, IBH. Publishing Co., New Delhi, India.

Zaghloul, M.A.R. and Atta-Alla, H.K. (2001). Effect of irrigation, sewage sludge and cement dust on the vegetative growth, flowering and chemical composition of gladiolus grown in sandy soil. Annals. Agric. Sci., Moshtohor, 39(1):565-583.

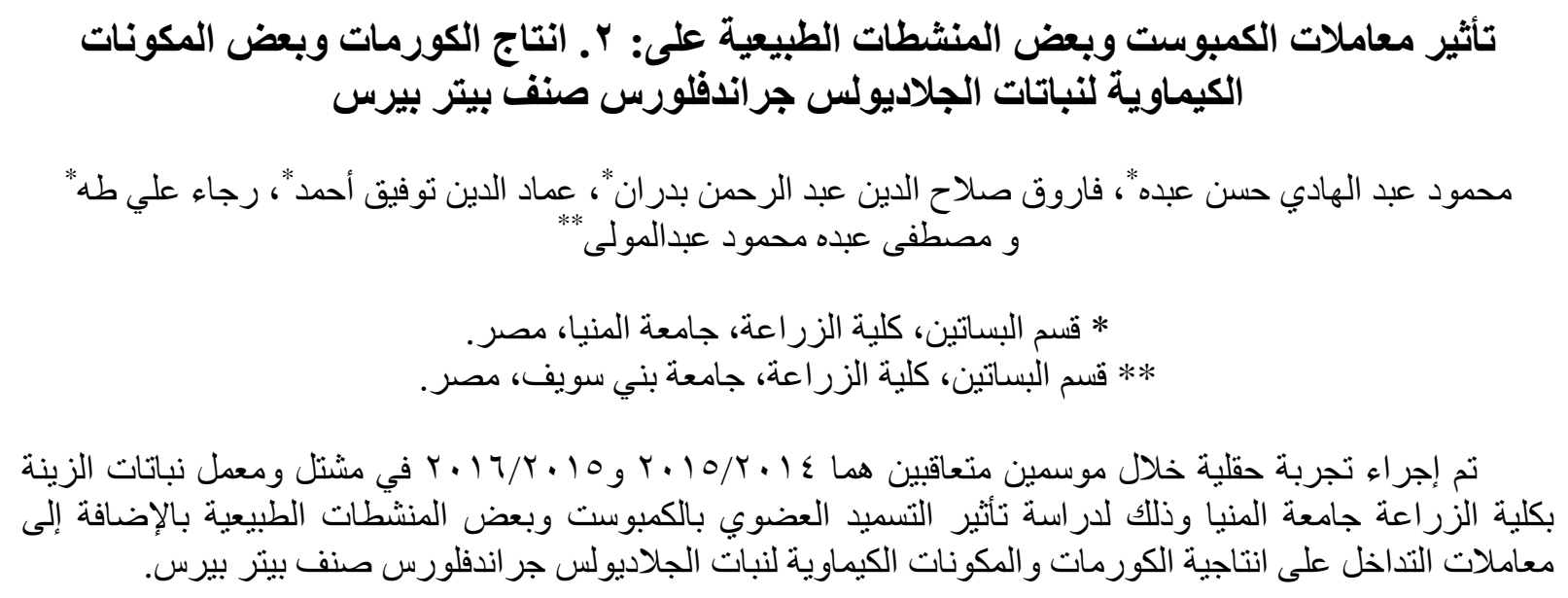




\section{M.A.H. Abdou et al.}

أظهرت النتائج أن صفات انتاج الكورمات والكريمات (قطر الكورمة وعدئ الكورئات الكريمات و الوزن الجاف للكريمات)

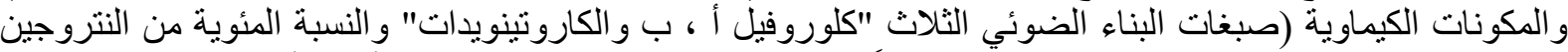

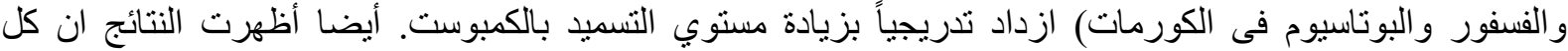

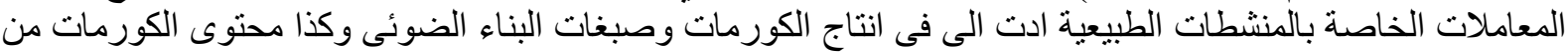

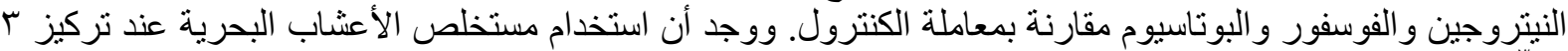

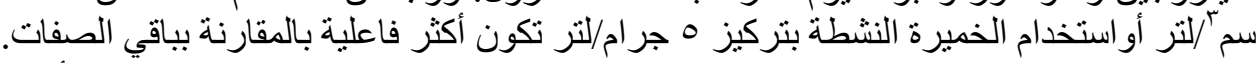

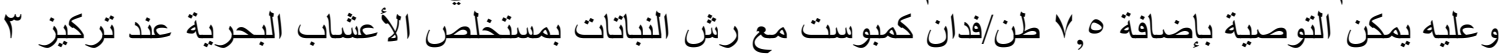

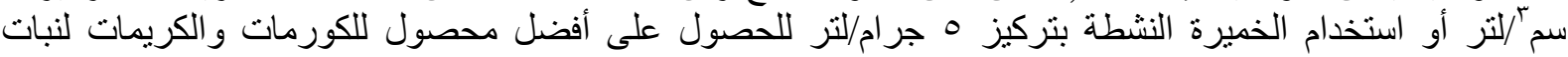

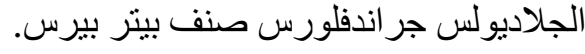

